\title{
FREE RADICAL ATTACK ON MEMBRANE LIPID AND ANTIOXIDANT VITAMINS IN THE COURSE OF PRE- ECLAMPTIC PREGNANCY
}

\author{
Adeniran S Atiba', Fayeofori M Abbiyesuku', Temitope A 'Niran-atiba', \\ Dolapo P Oparinde ${ }^{4}$, Olabamiji A Ajose ${ }^{5}$, Rasaq A akindele ${ }^{6}$
}

\section{ABSTRACT}

BACKGROUND: Despite the volume of knowledge and daily reports on pre-eclampsia, its pathogenesis is still yet to be ascertained. Oxidative stress (oxidant (free radical) in excess of antioxidant) injury is one of the recently suggested pathogenetic mechanisms. This study, however, was designed to determine second and third trimesters of plasma malondialdehyde (product of free radical attack on membrane lipid) and vitamins $C$ and $E$ in pre-eclamptic Nigerian women.

SUBJECTS AND METHODS: A Total of 100 subjects, each for pre-eclamptic, apparently normal and non-pregnant women qualified for the study. Venous blood samples were taken in the second and third trimesters of pregnancy and at the point of contact for non-pregnant women. Variables were analyzed using SPSS version 16, taking level of significance to be 0.05 .

RESULTS: Plasma malondialdehyde in the third trimester of normal pregnancy $(2.03 \pm 0.71 \mu m o l / l)$ was found to be significantly higher than the one in the second trimester $(1.65 \pm 0.62 \mu \mathrm{mol} / \mathrm{l})(p<0.0001)$. For pre-eclamptic subjects, the malondialdehyde in the third trimester $(3.13 \pm 0.61 \mu \mathrm{mol} / \mathrm{l})$ was also higher than the malondialdehyde in the second trimester $(3.00 \pm 1.21 \mu m o l / l)$.The mean vitamin $C$ values for subjects with normal pregnancy were similar in the second and third trimesters $(38.25 \pm 19.66 \mathrm{vs}$. 38.66 $\pm 19.40 ; p=0.882$ ). For subjects with pre-eclampsia, the mean Vit $C$ values were also similar in the $2^{\text {nd }}$ and $3^{\text {rd }}$ trimesters $(35.05 \pm 18.37 v s .37 .20 \pm 24.44 \mu \mathrm{mol} / \mathrm{l} ; \mathrm{p}=0.175)$.Mean vitamin $E$ values in the second and third trimesters were also similar for subjects with normal pregnancy $(28.62 \pm 13.85 \mathrm{vs}$. $28.50 \pm 13.35 \mu \mathrm{mol} / \mathrm{l} ; \mathrm{p}=0.950)$. A similar finding was observed in pre-eclamptic subjects $(25.09 \pm 12.79 \mathrm{vs}$. $28.00 \pm 14.83 \mu \mathrm{mol} / \mathrm{l} ; \mathrm{p}=0.067)$.

CONCLUSION: There was an increased product of membrane lipid attack (malondialdehyde) with no change in plasma levels of vitamins $C$ and $E$ as pregnancy advances into the third trimester of both normal and pre-eclamptic pregnancies. Antioxidant vitamins may not be useful in stopping the progression of free radical attack on membrane lipid to control pre-eclampsia.

KEYWORDS: Lipid peroxidation, Malondiadehyde, Free radical, Pre-eclampsia, Trimester, Vitamins

DOI: http://dx.doi.org/10.4314/ejhs.v24i1.5

\footnotetext{
${ }^{1}$ Department of Chemical Pathology, Ekiti State University Teaching Hospital, Ado-Ekiti, Ekiti State, Nigeria

${ }^{2}$ Department of Chemical Pathology, University College Hospital, Ibadan, Oyo State, Nigeria

${ }^{3}$ Department of Biomedical Science, Ladoke Akintola University of Technology, Osogbo, Osun State, Nigeria

${ }^{4}$ Department of Chemical Pathology, Ladoke Akintola University of Technology Teaching Hospital, Osogbo, Osun

State, Nigeria

${ }^{5}$ Department of Chemical Pathology, Obafemi Awolowo University, Ile-ife, Nigeria

${ }^{6}$ Department of Obstetrics and Gynaecology, Ladoke Akintola University of Technology Teaching Hospital, Osogbo,

Osun State, Nigeria

Corresponding Author: Adeniran S Atiba, Email: atiadesam08@yahoo.com
} 


\section{INTRODUCTION}

Pregnancy, though a physiological process, is associated with some complications especially during the first gestation. This has been linked with changes in body metabolism in which oxidative stress and accumulation of lipid peroxidation products are being implicated (1-5).

Pre-eclampsia and eclampsia are among the most serious complications of pregnancy in Nigeria (6). Despite the volume of knowledge on pre-eclampsia and eclampsia, studies have continued on a daily basis to unravel the roles and contributions of different pathologic mechanisms implicated. One of the implicated aetiopathologic mechanisms is the role of oxidative stress as a result of free radical injury. Oxidative stress is a result of imbalance between oxidant and antioxidant in favor of the oxidant (7). Oxidants are produced normally in aerobic metabolism but could be elevated in some pathological conditions (8-9).

Idogun et al in 2008 (10) observed a low antioxidant capacity in Nigerian pregnant women in a study done in South- south Nigeria. Guptal et al in 2009 (11) in their study established that preeclampsia is associated with increased concentration of oxidative stress markers including lipid peroxidation product (malondialdehyde) and a reduction in antioxidant concentration. Endothelial dysfunction secondary to oxidative stress has been implicated as a major pathological pathway in the development of hypertensive disorders of pregnancy (HDP) (12). Reduced serum antioxidant vitamins $\mathrm{A}$ and $\mathrm{E}$ have been reported in pre-eclampsia (13). Plasma malondialdehyde has also been observed to be lower in patients placed on vitamin $\mathrm{C}$ supplement (14).

It is envisaged that increased free radical activity leading to oxidative stress arises from production of free radicals or deficiency in protective antioxidant system (12). Injury to the cell as a result of free radicals may be due to its attack on membrane polyunsaturated lipid which is one of the most susceptible parts of the cell membrane. There are reports that suggest that there are increased free radical activities in hypertensive disorders of pregnancy (HDP) (4-5, 15-16).
Despite the increased volume of knowledge on oxidative stress as a factor in explaining the pathogenesis of pre-eclampsia from various parts of the world, studies that compare plasma malondialdehyde (MDA), vitamins $\mathrm{E}$ and $\mathrm{C}$ in the course of pre-eclamptic pregnancy is scarce. This study was, therefore, designed to determine the changes in plasma levels of malondialdehyde (MDA) and vitamins $\mathrm{E} \& \mathrm{C}$ in pre-eclamptic subjects in Osogbo, Nigeria.

\section{MATERIALS AND METHODS}

The study sites were pregnancy booking clinics of Ladoke Akintola University of Technology Teaching Hospital, Osogbo and Egbedore Local Government Health Centre, Awo, Osun State in Nigeria.

This study was a longitudinal cohort prospective one conducted over a period of 9 months between May 2011 and January, 2012. Sampling was simple random technique and each patient was followed up for a period of eight weeks. Patients at the time of recruitment were between 20 and 27 weeks of gestation.

A total of 118 and 115 subjects were recruited for pre-eclamptic and apparently normal pregnant women respectively out of which 100 (for each) were finally selected to be included in the study. The calculated sample size was 86.67 taking the prevalence of $6 \%$ for pre-eclampsia in Nigerian was used based on reports from previous studies (18-19). All subjects selected from the booking clinic in their second trimester, from 20 weeks and above, were followed up to their third trimester. All the selected subjects at first contact were all above 20 weeks of gestation. The criteria used to include pre-eclamptic women were elevated blood pressure of greater than 140/90 $\mathrm{mmHg}$ taken on two consecutive recordings at interval of 4-6 hours occurring in previously normotensive women or a rise in baseline systolic and diastolic blood pressure of 30 and $15 \mathrm{mmHg}$ respectively. Pre-eclamptic subjects also had a minimum proteinuria of $300 \mathrm{mg}$ in 24 hours urine sample or $1+$ in dipstick urinalysis. One hundred age-matched, apparently healthy nonpregnant women were also recruited from the general population as a control. Women with other complications of pregnancy such as gestational diabetes, multiple gestation and cancer coexisting 
with pregnancy were excluded from the study. All the recruited subjects were not on vitamins $C$ and E supplements. However, pre-eclamptic subjects were still on their regular treatment for preeclampsia. They were placed on Nifedipine or Aldomet and some low dose of aspirin was included in the treatment.

Ethical clearance to carry out the study was obtained from the Ethical Committee of Ladoke Akintola University of Technology Teaching Hospital, Osogbo.

About $10 \mathrm{mls}$ of venous blood was collected in the second and third trimesters of normal and pre-eclamptic pregnant groups into lithium heparin specimen bottle from antecubital fossa following aseptic procedure of venepuncture. Similarly, venous sample was taken from nonpregnant controls at the point of contact. Each batch of samples was centrifuged at $3000 \mathrm{~g}$ for 5mins. Plasma was separated carefully into plain screw cap specimen bottles and these were kept at$20^{\circ} \mathrm{C}$ before analysis. Plasma sample was used for MDA and vitamins $\mathrm{C}$ and $\mathrm{E}$ analysis. Vitamins $\mathrm{C}$ and E were assayed using the Waters 616 HPLC machine manufactured by the Waters Corporation, USA. HPLC reagent, Chromosystem HPLC kit manufactured by chromosystems Instruments \& Chemicals, Munchen, Germany) was used. Plasma samples previously stored at $-20^{\circ} \mathrm{C}$ were used; Plasma MDA was analyzed by method of Satoh $e t$ al (20). . Each of these biochemical parameters were run in a batch of 50 samples.

Data were entered and analyzed using Statistical Package for the Social Sciences (SPSS) 16.0. Continuous variables: age, gestational age, systolic and diastolic blood pressure were analyzed using mean \pm SD. Biochemical variables: urine protein, malondialdehyde, vitamins $\mathrm{C}$ and $\mathrm{E}$ were summarized using frequency and mean \pm SD. Measures of associations within biochemical variables, malondialdehyde and vitamins $\mathrm{C}$ and $\mathrm{E}$ were carried out using t-test, analysis of variance (ANOVA) and Spearman Correlation Coefficient. Level of significance was put at $p<0.05$

\section{RESULTS}

There was no statistically significant change in the mean age of the study subjects $(\mathrm{p}=0.169)$; nonpregnant group $(\mathrm{NonP})=27.3 \pm 5.3$ years; normal pregnancy group $(\mathrm{NP})=28.9 \pm 6.6$ years; preeclamptic pregnancy group $(\mathrm{PE})=28.9 \pm 4.3$ years).The mean gestational age of pre-eclamptic subjects $(24.3 \pm 5.8$ weeks $)$ was similar with that of normal pregnant women $(24.0 \pm 1.7$ weeks $)$ $(\mathrm{p}=0.681)$. This is illustrated in table 1 .

Table 1: Age and Gestational Age Distribution of Subjects

\begin{tabular}{llll}
\hline & Non - Pregnancy & Normal pregnancy & Pre-eclamptic pregnancy \\
\hline Mean Age (yr) & $27.3 \pm 5.3$ & $28.9 \pm 6.6$ & $28.9 \pm 4.3$ \\
Mean Gestational Age & & $24.0 \pm 1.7$ & $24.3 \pm 5.8$ \\
\hline
\end{tabular}

As illustrated in tables 2 and 3, the highest levels of MDA were seen in the pre-eclamptic subjects $(2.87 \pm 0.91 \mu \mathrm{mol} / \mathrm{l})$ while the lowest levels were seen in the non-pregnant subjects $(0.96 \pm 0.67$ $\mu \mathrm{mol} / \mathrm{l})$. In the second trimester, plasma malonaldehyde in pre-eclamptic subjects $(3.00 \pm 1.21 \mu \mathrm{mol} / \mathrm{l})$ was found to be significantly higher than in non-pregnant group $(0.96 \pm 0.67$ $\mu \mathrm{mol} / \mathrm{l}) ; \mathrm{p}<0.05$. Similarly, in the second trimester, plasma MDA level was observed to be higher in the pre-eclamptic pregnant group $(3.00 \pm 1.21 \mu \mathrm{mol} / \mathrm{l})$ than in normal pregnant group $(1.65 \pm 0.62 \mu \mathrm{mol} / \mathrm{l})$. This difference was statistically significant at $p<0.05$. In the third trimester of pregnancy, similar findings were observed with significantly higher plasma levels of MDA observed in pre-eclamptic group $(3.13 \pm 0.61 \mu \mathrm{mol} / \mathrm{l})$ than that in normal pregnancy group $(2.03 \pm 0.71 \mu \mathrm{mol} / \mathrm{l}) ; \mathrm{p}<0.05$. In the same vien, in the third trimester, there was higher plasma MDA observed in normal pregnant group $(2.03 \pm 0.71 \mu \mathrm{mol} / \mathrm{l})$ than in non-pregnant group $(0.96 \pm 0.67 \mu \mathrm{mol} / \mathrm{l})$. This difference was statistically significant $(\mathrm{p}<0.0001)$. Plasma MDA in the third trimester of normal pregnancy $(2.03 \pm 0.71 \mu \mathrm{mol} / \mathrm{l})$ was found to be significantly higher than in the second trimester $(1.65 \pm 0.62 \mu \mathrm{mol} / \mathrm{l})(\mathrm{p}<0.0001)$. For pre-eclamptic subjects, the MDA in the third trimester $(3.13 \pm 0.61 \mu \mathrm{mol} / \mathrm{l})$ was higher than in the second trimester $(3.00 \pm 1.21 \mu \mathrm{mol} / 1)$, but the difference was not statistically significant $(\mathrm{p}=0.312)$. 
Table 2: Variables among the Study Groups in the Second and Third Trimesters

\begin{tabular}{llllll}
\hline Variable & & Group Mean & Second Trimester & Third Trimester & p-Value \\
\hline Urine Pr $(\mathbf{g} / \mathbf{l})$ & PE & $40.71 \pm 33.54$ & $50.51 \pm 39.54$ & $30.90 \pm 27.53$ & $<0.001$ \\
\hline SBP & NonP & $126.33 \pm 11.22$ & $126.33 \pm 11.22$ & $126.33 \pm 11.22$ & 1 \\
& NP & $128.73 \pm 16.53$ & $131.30 \pm 22.21$ & $126.22 \pm 10.85$ & 0.311 \\
& PE & $151.58 \pm 21.30$ & $166.15 \pm 19.37$ & $137.00 \pm 23.23$ & $<0.001$ \\
\hline DBP & NonP & $75.99 \pm 07.66$ & $75.99 \pm 07.66$ & $75.99 \pm 07.66$ & 1 \\
& NP & $82.36 \pm 10.08$ & $81.60 \pm 10.92$ & $83.11 \pm 09.23$ & 0.121 \\
& PE & $86.2 \pm 10.38$ & $90.80 \pm 8.81$ & $81.60 \pm 11.95$ & $<0.001$ \\
\hline MDA $(\mu \mathrm{mol} / \mathbf{l})$ & NonP & $0.96 \pm 0.67$ & $0.96 \pm 0.67$ & $0.96 \pm 0.67$ & 1 \\
& NP & $1.84 \pm 0.67$ & $1.65 \pm 0.62$ & $2.03 \pm 0.71$ & $<0.0001$ \\
& PE & $2.87 \pm 0.91$ & $3.00 \pm 1.21$ & $3.13 \pm 0.61$ & 0.312 \\
\hline Vit C $(\mu \mathrm{mol} / \mathrm{l})$ & NonP & $41.00 \pm 23.24$ & $41.00 \pm 23.24$ & $41.00 \pm 23.24$ & 1 \\
& NP & $38.46 \pm 19.53$ & $38.25 \pm 19.66$ & $38.66 \pm 19.40$ & 0.882 \\
& PE & $37.13 \pm 21.41$ & $35.05 \pm 18.37$ & $37.20 \pm 24.44$ & 0.175 \\
\hline Vit E $(\mu \mathrm{mol} / \mathrm{l})$ & NonP & $30.24 \pm 14.09$ & $30.24 \pm 14.09$ & $30.24 \pm 14.09$ & 1 \\
& NP & $28.56 \pm 13.6$ & $28.62 \pm 13.85$ & $28.50 \pm 13.35$ & 0.950 \\
& PE & $26.90 \pm 13.81$ & $25.09 \pm 12.79$ & $28.00 \pm 14.83$ & 0.067 \\
\hline
\end{tabular}

* Statistically significant $(p<0.05)$

Table 3: Comparison of Malondialdehyde (Mda) $\left(\right.$ Mean \pm SD) in the $2^{\text {nd }}$ and $3^{\text {rd }}$ Trimesters across Study Groups

\begin{tabular}{llll}
\hline Variables & Study group & Mean $(\mu \mathrm{mol} / \mathrm{l})$ & $\mathrm{p}$-Value \\
\hline MDA in $2^{\text {nd }}$ Trimester & NonP Vs NP & $0.96 \pm 0.67$ Vs $1.65 \pm 0.62$ & $>0.05$ \\
& NonP Vs PE & $0.96 \pm 0.67$ Vs 3.00 \pm 1.21 & $<0.05$ \\
& NP Vs PE & $1.65 \pm 0.62$ Vs $3.00 \pm 1.21$ & $<0.05$ \\
\hline \multirow{2}{*}{ MDA in $3^{\text {rd }}$ Trimester } & NonP Vs NP & $0.96 \pm 0.67$ Vs $2.03 \pm 0.71$ & $<0.001$ \\
& NonP Vs PE & $0.96 \pm 0.67$ Vs $1.73 \pm 0.61$ & $<0.001$ \\
& NP Vs PE & $2.03 \pm 0.71$ Vs $1.73 \pm 0.61$ & $<0.001$ \\
\hline
\end{tabular}

NP-Normal pregnant women, PE- Pre-eclamptic women, NonP-Non pregnant women, $*$ Statistically significant $(p<0.05)$

Group mean vitamin $\mathrm{C}$ levels were highest in nonpregnant subjects $(41.00 \pm 23.24 \mu \mathrm{mol} / \mathrm{l})$ and lowest in the pre-eclamptic subjects $(37.13 \pm 21.41 \mu \mathrm{mol} / \mathrm{l})$ . In the second trimester, plasma vitamin $\mathrm{C}$ levels were observed to be lower in pre-eclamptic group $(35.05 \pm 18.37 \mu \mathrm{mol} / \mathrm{l})$ than in normal pregnancy group $(38.25 \pm 19.66 \mu \mathrm{mol} / \mathrm{l})$ although the difference was not statistically significant $(p=0.268)$. By the same token, in the second trimester, lower plasma vitamin $\mathrm{C}$ level was found in subjects with pre-eclampsia $(35.05 \pm 18.37 \mu \mathrm{mol} / \mathrm{l})$ than in nonpregnant subjects $(41.00 \pm 23.24 \mu \mathrm{mol} / \mathrm{l})$; this difference was statistically significant at $\mathrm{p}=0.045$ has shown in table $4 \mathrm{~b}$ below. Similar findings were observed in the third trimester, i.e.lower level of vitamin C was observed in pre-eclamptic subjects $(37.20 \pm 24.44 \mu \mathrm{mol} / \mathrm{l})$ when compared with normal pregnancy group $(38.66 \pm 19.40)$. This difference was not statistically significant $(\mathrm{p}=0.863)$. Although not statistically significant $(\mathrm{p}=0.436)$, in the third trimester, lower plasma vitamin $\mathrm{C}$ was observed in patients with pre-eclampsia $(37.20 \pm 24.44 \mu \mathrm{mol} / \mathrm{l})$ than in nonpregnant group $(41.00 \pm 23.24 \mu \mathrm{mol} / \mathrm{l})$. The mean vitamin $\mathrm{C}$ level was also observed in the third trimester to be lower in normal pregnancy group $(38.66 \pm 19.40$ $\mu \mathrm{mol} / \mathrm{l})$ when compared with nonpregnant subjects. This difference was not statistically significant $(\mathrm{p}=0.360)$. The mean vitamin $\mathrm{C}$ values for subjects with normal pregnancy were similar in second and third trimesters $(38.25 \pm 19.66 \mathrm{Vs}$ 
$38.66 \pm 19.40 ; \mathrm{p}=0.882)$. For subjects with preeclampsia, the mean vitamin $\mathrm{C}$ values were also similar in the second and third trimesters
$(35.05 \pm 18.37$ Vs $37.20 \pm 24.44 \mu \mathrm{mol} / \mathrm{l} ; \mathrm{p}=0.175)$. This is as shown in table 4.

Table 4: Comparison of Antioxidant Vitamins (Mean \pm SD) in $2^{\text {nd }}$ And $3^{\text {rd }}$ Trimesters across Study Groups

\begin{tabular}{|c|c|c|c|}
\hline Variables & Study Group & Mean $(\mu \mathrm{mol} / \mathrm{l})$ & p-value \\
\hline Vitamin C $2^{\text {nd }}$ & NonP Vs NP & $41.00 \pm 23.24$ Vs $38.25 \pm 19.66$ & 0.352 \\
\hline \multirow[t]{2}{*}{ Trimester } & NonP Vs PE & $41.00 \pm 23.24$ Vs $35.05 \pm 18.37$ & 0.045 \\
\hline & NP Vs PE & $38.25 \pm 19.66$ Vs $35.05 \pm 18.37$ & 0.268 \\
\hline Vitamin C $3^{\text {rd }}$ & NonP Vs NP & $41.00 \pm 23.24$ Vs $38.66 \pm 19.40$ & 0.360 \\
\hline \multirow[t]{2}{*}{ Trimester } & NonP Vs PE & $41.00 \pm 23.24$ Vs $37.20 \pm 24.44$ & 0.436 \\
\hline & NP Vs PE & $38.66 \pm 19.40$ Vs $37.20 \pm 24.44$ & 0.863 \\
\hline Vitamin E $2^{\text {nd }}$ & NonP Vs NP & $30.24 \pm 14.09$ Vs $28.62 \pm 13.86$ & 0.40 \\
\hline \multirow[t]{2}{*}{ Trimester } & NonP Vs PE & $30.24 \pm 14.09$ Vs $25.09 \pm 12.79$ & 0.008 \\
\hline & NP Vs PE & $28.62 \pm 13.86$ Vs $25.09 \pm 12.79$ & 0.068 \\
\hline Vitamin E $3^{\text {rd }}$ & NonP Vs NP & $30.24 \pm 14.09$ Vs $28.50 \pm 13.35$ & 0.456 \\
\hline \multirow[t]{2}{*}{ Trimester } & NonP Vs PE & $30.24 \pm 14.09$ Vs $28.00 \pm 14.83$ & 0.372 \\
\hline & NP Vs PE & $28.50 \pm 13.35$ Vs $28.00 \pm 14.83$ & 0.919 \\
\hline
\end{tabular}

NP-Normal pregnant women, PE- Pre-eclamptic women, NonP-Non pregnant women, *Statistically significant $(p<0.05)$

As a group, mean plasma vitamin E levels were highest in the non-pregnant subjects $(30.24 \pm 14.09 \mu \mathrm{mol} / \mathrm{l})$ and lowest in subjects with pre-eclampsia $(26.90 \pm 13.81 \mu \mathrm{mol} / \mathrm{l})$. In the second trimester, mean plasma vitamin $\mathrm{E}$ was observed to be significantly lower in pre-eclamptic pregnancy $(25.09 \pm 12.79 \mu \mathrm{mol} / \mathrm{l})$ in comparison with nonpregnant group $(30.24 \pm 14.09 \mu \mathrm{mol} / \mathrm{l}) ; \mathrm{p}<0.005$. Also, in the second trimester, lower value of vitamin $\mathrm{E}$ was found in pre-eclamptic group $(25.09 \pm 12.79 \mu \mathrm{mol} / \mathrm{l})$ than in normal pregnancy group $(28.62 \pm 13.86 \mu \mathrm{mol} / \mathrm{l})$; however, this difference was not statistically significant $(p=0.068)$. The finding in the third trimester is not different-plasma lower levels of vitamin $E$ were observed in pre-eclamptic group $(25.09 \pm 12.79$ $\mu \mathrm{mol} / \mathrm{l})$ in comparison with normal pregnancy subjects $(28.50 \pm 13.35 \mu \mathrm{mol} / \mathrm{l})$. This difference was not statistically significant $(\mathrm{p}=0.919)$. Similarly, in the third trimester, the plasma level of vitamin $\mathrm{E}$ was observed to be lower in pre-eclamptic group $(25.09 \pm 12.79 \mu \mathrm{mol} / \mathrm{l})$ than in the nonpregnant group $(30.24 \pm 14.09 \mu \mathrm{mol} / \mathrm{l})$. However, this differece was not statistically significant $(\mathrm{p}=0.37)$. The values for the second and third trimesters were similar for subjects with normal pregnancy (28.62 \pm 13.85 Vs $28.50 \pm 13.35 \mu \mathrm{mol} / \mathrm{l} ; \mathrm{p}=0.950)$. A similar finding was observed in pre-eclamptic subjects $(25.09 \pm 12.79$ vs. $28.00 \pm 14.83 ; \mathrm{p}=0.067)$.

\section{DISCUSSION}

The mean age of non-pregnant women was not statistically significant when compared with the other two study groups. In the present study, mean gestational age among the study groups falls within the same range. Obesity, ageing as well as increased gestational age have been found to influence some biochemical parameters like malondialdehyde (MDA) $(21,22)$. There were significant differences in systolic and diastolic blood pressure as well as urinary protein-they were higher in pre-eclamptic pregnant women than in the control groups, and this is expected as regards the basis of diagnosing pre-eclampsia. Systolic and diastolic blood pressure and urinary protein were significantly lowered in third trimester than in second trimester. This may indicate some level of improvement in the clinical condition of women with pre-eclampsia.

In the course of the reaction of free radical with polyunsaturated membrane lipid, a product known as malondialdehyde is produced and this is currently being used as an index of free radical injury because it is more stable in the system. In 
our study, we observed an increase in plasma malondialdehyde level in pre-eclamptic women when compared with normal pregnant and nonpregnant women in the second trimester of pregnancy. Similar findings were observed in the third trimester. Our finding is in agreement with similar studies which reported a significantly elevated level of malondialdehyde in both normal and pre-eclamptic pregnant women $(22,23)$. Some previous studies showed that malondialdehyde was found to be progressively increasing in the course of pregnancy and can be used to predict occurrence of pre-eclampsia in the third trimester of pregnancy $(21,24)$. As regards plasma levels of malonadildehyde in the second and third trimesters, significantly higher levels were observed in the third trimester of normal and preeclamptic pregnant women. However, the value observed in the pre-eclamptic group was not statistically significant. This may be due to reduced disease burden as evidenced by lower blood pressure and urinary protein in the third trimester. Ilhan et al in 2002 reported similar findings (21). Vascular endothelial damage that results from free radical generation and possibly pre-eclampsia may have started from 20 weeks of pregnancy and may worsen with increasing demand of oxygen from maternal circulation by growing placenta.

Vitamin $\mathrm{C}$ is an antioxidant which may be referred to as reducing agent. It reacts with superoxide and other lipid hydroperoxide radicals. This study observed plasma vitamin $\mathrm{C}$ level to be higher in women with apparently normal pregnancy than in those with pre-eclampsia in the second and third trimesters, which is not statistically significant. However, a significantly higher value in non-pregnant women than in preeclamptic women was found in the second trimester but not in the third trimester. The pathological burden of pre-eclampsia and persistent physiology of normal pregnancy may have overwhelmed the availability of vitamin $\mathrm{C}$ which is being used to scavenge some free radicals being produced. It was observed by Luqman et al in Ilorin, Northern Central Nigeria, that women on vitamin $\mathrm{C}$ supplement tend to have reduced levels of free radical injury as shown by lower level of malondialdehyde than in a control group not on vitamin C supplement (14). This could be true because of inability of humans to synthesis vitamin C. In the present study, no significant changes in vitamin $\mathrm{C}$ levels were observed in both second and third trimesters of normal and preeclamptic pregnancies. This is contrary to the work of Luqman et al 2008 (14) and Hassan et al 2006 (25) who observed decreasing level of vitamin $\mathrm{C}$ as pregnancy advances, though their sample size was small and dietary exposure may be different. However, our observation can be the result of increasing gestational age which is usually accompanied with increase tissue demand of nutrients and increase appetite.

Antioxidant vitamins, especially vitamin E, are the most important chain breaking antioxidants, and they protect polyunsaturated fatty acid from peroxidation damage by donating hydrogen to the lipid peroxyl radical and vitamin E itself does not become a free radical as in the case with some antioxidant (26). This and its lipophilic nature vitamin E make it a good chain terminator in any lipophylic environment. In the present study, the plasma level of vitamin $E$ in normal and pre-eclamptic pregnancies was reduced compared to non-pregnant group both in the second and third trimesters. However, this was not statistically significant except for the comparison between non-pregnant and preeclamptic groups in the second trimester. On the other hand, lower value was found in some previous similar studies but with lower sample size than the present study $(13,25,27)$.

In conclusion, there was an increased plasma lipid peroxidation product (malondialdehyde) with no change in plasma levels of vitamins $\mathrm{C}$ and $\mathrm{E}$ as pregnancy advances into the third trimester of both normal and pre-eclamptic pregnancies. Therefore, studies focusing on another antioxidant probably antioxidant enzymes are necessary to identify the specific antioxidant to counteract lipid peroxidation (free radical injury). This may help in reducing the occurrence of pre-eclampsia as pregnancy advances.

\section{REFERENCES}

1. Kaja RJ. Greer LA. Manifestation of chronic disease during pregnancy. JAMA, 2005; 294 (21): 2751-7. 
2. Jonathan MM, Nitin KG, Marit JR., Elizabeth AL, Marian K. Circulating marker of oxidative stress is raised in normal pregnancy and preeclampsia. Briti J Obs Gyn, 1998; 105:1195-9.

3. Uchenna IN, Fedelis EE, Serum ascorbic acid levels during pregnancy in Enugu. Nigeria $J$ coll Med. 2005; 10(1):43-5.

4. Hubel, CA. Robert, JM, Taylor, RN. Lipid peroxidation in pregnancy: New perspectives on preeclampsia Am. J. Obstet. Gynecol, 1989; 161, 1025-1034.

5. Uotila, JT, Tuimala, RJ, Aarnio TM Pyykko KA, Ahotupa MO. Findings on lipid peroxidation and antioxidant function in hypertensive complications of pregnancy. Br. J. Obstet. Gynecol. 1993; 100(3), 270-276.

6. Vanderjagt DJ, Patel J, El-NAFATY AN, ElNafaty AU, Melah GS. High density lipoprotein and homocyteine levels scorrelate inversely in preeclampsia women in northern Nigeria. Acta Gynecol Scand, 2004 June, Vol 83(6): $536-543$.

7. Sies, H. Oxidative stress: Introduction in oxidative stress: In oxidative stress: oxidative stress: oxidants and antioxidant ed Sies $\mathrm{H}$. 19191; pp xv-xxiv. Academic press London

8. Johanna $\mathrm{H}$, Bengt $\mathrm{V}$, Anders L, Amar B. Association of type 2 diabetes with Cyclooxygenate - Mediated inflammation and oxidative stress in an elderly population. American Heart Association, Inc. 2004;109: 1729 - 1734.

9. Ogunro PS, Balogun WO, Fadero FF, Idogun E S, Oninla S O et al. Palsma lipid peroxidation and total antioxidant status among Dyslipidaemia and Hypertensive Nigerians with Risk of Coronary Heart Disease. West African Jornal of Medicine, 2009;28:87-91.

10. Idogun ES, Odiegwu ME, Momoh SM Okonofua FE. Effect of Pregnancy on total antioxidant capacity in Nigerian women. park J. Med Sci, 2008;24:2292-295.

11. Guptal, S.A, Sekhon L, Agarwal R. Nabil A, Rishi R $\mathrm{S}$ et al. Lipid Peroxidation and Antioxidant status in preeclampsia: a systemic review, Obstetrical and Gynaecological survey, 2009; 64(11):750 - 759.

12. Tsukatani E. Etiology of EPH- gastosis from the view of dynamics of vasoactive prostanoids. Lipid peroxides and vitamin E; Acta. Obstet, Gynaecol, 1983;35:713-720.

13. Yuping W. Antioxidant activities and mRNA expression of superoxide dismuthase, catalase and glutathione peroxidise in normal and preeclamptic placentas. Reproductive sciences, 1996;3(4): 179.

14. Luqman A, Salihu MA, Gafar A, Aremu IT, Soladoye AO. Effect of vitamin $\mathrm{C}$ on malondialdehyde in pregnant Nigerian women. Journal of Basic and Applied Science, 2008;4(2): 105-108.

15. Wu, J.J. Lipid peroxidation in preeclampsia and eclamptic pregnancies. Eur J Obstet Gynecol Report Biol, 1996; 64(1)51-54.

16. Peber J.S, Contran RS. Cytokines and endothelial cell biology. Rev. 1990; 70427 451.

17. Araoye MO. Subjects Selection In Research Methodology with Statistics for Health and Social Sciences. $1^{\text {st }}$ ed, Ilorin. Nathadox publisher, 2003;115-128.

18. Makinde ON, Adekoge OA, Adediran IA Ndububa D.A Adeyemi A.B et al. HELLP Syndrome: The experience at Ile-Ife, Nigeria. Journal of Obstetrics and Gynaecology, 2009;29(3):195-199.

19. Anorlu R.I, Iwuala NC, Odum CV. Risk factors for preeclampsia in Lagos, Nigeria. Aust NZ J Obstet Gynaecol, 2005;45(4): 278.

20. Satoh K. serum lipid peroxide in cardiovascular disorders determined by a new colourimetric method. Clin Chem, Acta.1978;90:37-42

21. Ilhan N, Ilhan N, Simsek M. the changes of trace elements malonaldehyde levels and superoxide dimuthase activities in pregnancy with or without pre-eclampsia. Clin Biochem, 2002;35(5):393-7.

22. Veronican MC, Jaime L, Alvaro C, David R, Jonge $\mathrm{AE}$ et al. oxidative Stress is closely related to clinical severity of pre-eclampsia. Biol Res, 2006; 39:229-239.

23. Kumar CA, Das UN. Lipid peroxide, antioxidants and nutric oxide in patients with preeclampsia and essential hypertension. Med Sci Monit, 2000; 6:901.

24. Basbug M, Demir I, Sernil S et al. Maternal erythrocyte malondialdehyde level inpreeclampsia prediction: a longitudinal study. J.Perinat Med. 2003;31(6):469-74. 
25. Hassan GI, Onu AB. Total vitamin C concentration in pregnant women: implications for a healthy pregnancy. Rev Bras Saude Matern Infant, 2006;6: 293-296.

26. Krisha MS, Venkataramana G. Status of lipid peroxidation, Gluthathione, Ascorbic Acid, Vit E. and Antioxidant enzymes in patients with pregnancy induced hypertension. India $J$. Physio Pharmacol, 2007;51(3):284-288.

27. Sahu S, Abraham R, Vedavalli R, Daniel M . Study of lipid profile, lipid peroxidation and vitamin $\mathrm{E}$ in pregnancy induced hypertension. Indian J physiol Pharmacol, 2009; 53(4):365369. 